\title{
Гігієнічна оцінка добової рухової активності дітей 7-17 років
}

\section{I. О. Калиниченко}

\author{
Інститут фізичної культури Сумського державного педагогічного університету \\ ім. А. С. Макаренка, Суми, Україна
}

\begin{abstract}
Резюме. Согласно шкале суточных энергозатрат суммарной суточной двигательной активности детей 7-17 лет, среди школьников трех возрастных групп суточные энергозатраты закономерно уменьшаются с возрастом в 1,96 раза $(t=6,64 ; p<0,05)$ и транспонируются в средний уровень энергозатрат, обусловленных особенностями учебной деятельности и более гиподинамичным образом жизни детей среднего и старшего школьного возраста. Половые различия двигательной активности минимизированы и характеризуются большими, по сравнению с девочками, энергозатратами у мальчиков 16 и 17 лет на 45,65 и 20 ккал. Суточные энергозатраты учеников сельских школ на 7,64 \% больше, чем у городских школьников.
\end{abstract}

Ключевые слова: суточная двигательная активность, дети, энергозатраты, нормирование, гиподинамический образ жизни.

Summary. According to the developed scale of daily energy total daily physical activity for children 7-17 years found, that among the three age groups of school children, the daily energy naturally decline with age in 1.96 times $(t=6.64 ; p<0.05)$ and transposed into the average level energy, which are due the peculiarities of educational activities and more hypodynamical way of life of children middle and senior school age. The gender differences of physical activity are minimized and characterized by the advantage of energy consumption among boys in 16 years, only on the $45.65 \mathrm{kcal}$ and $20 \mathrm{kcal}$ - at 17 years, in comparison with the girls.

Daily energy consumption of pupils of village schools on $7.64 \%$ more, than the energy consumption of city pupils.

Key words: daily physical activity, children, energy consumption, regulation, hypodynamic way of life.

Постановка проблеми. Рухова активність (PA) - найважливіший компонент способу життя і поведінки дітей - визначається соціальноекономічними умовами, рівнем культури, організацією фрізичного виховання (ФВ), доступністю спортивних споруд і місць відпочинку, індивідуально-типологічними особливостями вищої нервової діяльності та функціональними особливостями організму дітей [2, 10].

Пріоритетне місце у вирішенні проблеми збереження і зміцнення здоров'я дітей посідає розробка гігієнічно обгрунтованих норм рухової активності як засобу профрілактики впливу негативних чинників на здоров'я дітей і підлітків [6, 8]. У повсякденному житті звична РА школярів часто не відповідає тим біологічним потребам організму в русі, які сприяють зміцненню і збереженню здоров'я. Крім того, для способу життя сучасних школярів характерною $\epsilon$ шкільна гіпокінезія, причини якої зумовлені нераціональною організацією навчально-виховного процесу 3 перевантаженням навчальними заняттями, ігноруванням ФВ, відсутністю вільного часу $[3,4]$.
Проблема нормування РА - комплексна, оскільки ї̈ вирішення охоплює фрізіологічні, гігієнічні, психологічні, соціальні і фрілософські аспекти. За норму РА у дитячому віці визнається така величина, яка повністю задовольняє біологічні потреби в рухах, відповідає вимогам організму, сприяє його розвитку i зміцненню здоров'я $[1,9]$. Особливість гігієнічного нормування РА полягає в потребі встановити величину гранично допустимої і мінімально необхідної рухової активності. Критеріями гігієнічної норми $\epsilon$ задоволення біологічної потреби в рухах дітей і підлітків окремих статево-вікових груп, врахування фуннкціональних можливостей і фрізичної підготовленості різних колективів [1].

Мета дослідження - оцінити добову рухову активність дітей 7-17 років з метою її нормування.

Організація та методи дослідження. Для фрізіолого-гігієнічної характеристики рухової активності 984 школярів (Сумської, Київської областей) ми використовували такі методи: аналіз матеріалів анкетного опитування учнів за спеціально розробленою «Картою формалізованого 
самозвіту про рухову активність» та визначення енерговитрат таблично-хронометражним методом. За даними формалізованого звіту встановлено час, який витрачено протягом доби на різні (за інтенсивністю) категорії РА, визначено середні добові енерговитрати дітей та рівень РА як конкретної особи, так і груп дітей у цілому. Дані самозвіту кожного учня були розподілені за категоріями РА: фонова (базова), дуже легка, легка, середня, важка, дуже важка.

Енерговитрати під час виконання певного виду діяльності відповідали добутку енергетичної «вартості» виду роботи на її тривалість протягом доби. Величину енергетичної «вартості» кожного виду діяльності використано з попередніх наукових досліджень у вигляді показника MET (метаболічний екВіВалент фозичної актиВності) [5].

Результати дослідження та їх обговорення. За даними формалізованої самозвітності дітей і підлітків встановлено, що середньодобові енерговитрати становили 2 800,20 \pm \pm 9,01 ккал $\left(72,79 \pm 0,83\right.$ ккал $\left.\cdot \kappa^{-1}\right)$ у будні і $2471,40 \pm 11,61$ ккал $\left(64,56 \pm\right.$ 0,75 ккал • кг $\left.{ }^{-1}\right)-$ у вихідні.

Зважаючи на те, що форма, інтенсивність і характер РА дітей і підлітків шкільного віку змінюються в онтогенезі під впливом біологічних (віку, статі, стан здоров'я) і соціальних чинників, проведено зіставлення кількісних показників звичної РА у різних групах школярів.

У цілому, у віковому діапазоні 7-17 років, виявлено тенденцію до більшої РА хлопців, ніж дівчат у робочий день: добові енерговитрати хлопців становлять $2816,10 \pm 13,24$ ккал у будні і 2 465,50 \pm 17,53 ккал - у вихідні, дівчат, відповідно 2 783,10 $\pm 12,24$ ккал $(t=1,82, p>0,05)$ і $2474,80 \pm 15,51$ ккал $(t=0,39, p>0,05)$. Як свідчать результати дослідження серед школярів трьох вікових груп, добові енерговитрати закономірно збільшуються з віком.

Слід зазначити, що РА у вихідний день $€$ дефріцитною по відношенню до РА будня. Причому дефріцитність PA $€$ майже однаковою в усіх вікових групах (серед дітей молодшого шкільного віку - 12,49 \%, середнього - 12,23 \%, старшого - 10,18 \% добового бюджету часу робочого дня), що свідчить про гіподинамічний спосіб життя школярів і має загрозливу перспективу для здоров'я та розвитку дітей. Отримані дані не збігаються з результатами попередніх досліджень [9], у яких доведено перевагу обсягу РА школярів у вихідний день, і підтверджують припущення про зниження мотиваційно-ціннісних потреб школярів до активного відпочинку і здорового способу життя. Крім того, статево-вікові відмінності
РА дітей 7-17 років полягають у тому, що збільшення РА у віковому діапазоні 10 років відбувається не лінійно. Обсяг енерговитрат у дівчаток і хлопчиків семи років знаходиться на одному рівні. У подальшому добова РА хлопців зберігається вищою, ніж у дівчат.

Зіставлення отриманих даних із результатами досліджень, що висвітлені у вітчизняній та зарубіжній літературі 1970-1990-х років [10], показало, що характерна вікова динаміка добових енергетичних витрат у цілому зберігається і полягає у зниженні її у двох вікових діапазонах (9-10 та 14-15 років).

Перший віковий період характеризується фрормуванням режиму жорсткої регламентації PA і вільного часу під впливом умов навчання, переходом з початкової школи до старших класів, що вимагає більш раціонального використання вільного часу і обмеження задоволення природної потреби у рухах, яке було притаманне у молодшому шкільному віці.

Другий віковий період збігається з фрормуванням пріоритетності соціальних фрункцій у житті підлітків, що супроводжується домінуванням мотиваційно-ціннісних орієнтацій над біологічними потребами у русі і скороченням вільного часу за рахунок навчальної діяльності або гіподинамічних фрорм дозвілля. Однак між отриманими даними анкетування та результатами наукових досліджень попередніх років встановлено розбіжності, які стосуються гендерних відмінностей і полягають у тому, що різниця добових енергетичних витрат хлопців і дівчат 1970-х років становила 800 і 1000 ккал у 16 і 17 років, тоді як на сьогодні статеві відмінності мінімізовані і характеризуються переважанням енерговитрат PA хлопців у 16 років лише на 45,65 ккал і у 17 років - на 20,95 ккал порівняно із дівчатамиоднолітками. Очевидно, встановлені закономірності $€$ наслідком змін, що відбулися за останні десятиліття в організації навчального процесу із впровадженням нових фрорм навчання, інфрормаційних і технічних інновацій, зміною структури вільного часу школярів, використання ПК у години дозвілля і зростанням непопулярності оздоровчої фрізичної активності.

На підставі дисперсійного аналізу визначено, що обсяг РА залежав від типу навчального закладу тільки у робочий день $(F=2,05 ; p=0,017)$, зважаючи на відмінності в обсязі організованої PA у школах. У вихідний день РА забезпечується тільки самоорганізацією дозвілля дітей, що свідчить про низьку активність навчальних закладів у організації позанавчальної фрізкультурно-масової роботи серед школярів. 
Іншою важливою характеристикою звичної PA школярів $\epsilon$ тривалість ії структурних компонентів. Найбільшу питому вагу має фонова РА, що характеризує закономірне зменшення з віком тривалості сну (з $36,37 \pm 0,53 \%$ у 7 років до $32,78 \pm 0,49 \%$ у 17 років, $p<0,01)$. Питома вага легкої РА формується за рахунок часу, що пов'язаний з незначними енерговитратами (уроки в школі, дорога пішки до школи та до дому, особиста гігієна). Зменшення тривалості фонової РА відбувається за рахунок збільшення дуже легкого компонента PA (час виконання домашнього завдання, робота на ПК, перегляд телепередач, читання) з 17,29 $\pm 0,68 \%$ до $21,53 \pm 0,73 \%$ $(p<0,01)$ та середнього компонента РА (відповідно з 4,75 $\pm 0,34 \%$ у 7 років до 7,18 $\pm 0,51 \%$ добового бюджету часу у 17 років, $p<0,01$ ). Причому збільшення тривалості категорії РА середнього рівня у підлітковому віці відбувається за рахунок витрати часу на роботу по господарству, прогулянки, ранкову гімнастику, рухливі ігри.

Звичайно, найбільший рівень енергетичного навантаження має висока категорія РА, що досягається заняттями у спортивних секціях, активним відпочинком із використанням спортивних ігор, плавання, ходьби на лижах, їзди на велосипеді, спеціально організованими заняттями фізичними вправами у спортивних клубах. Аналіз категорії РА високого рівня доцільно було б провести згідно з концепцією Р. В. Силла, суть якої полягає у тому, що гігієнічне нормування оптимального обсягу РА, яка $€$ стимулом розвитку молодого організму і зміцнює здоров'я, повинне базуватися на тривалості «корисної» PA з підвищенням обміну речовин у 5-10 разів, порівняно із станом спокою (із частотою пульсу 130-160 уд $\cdot \mathrm{xв}^{-1}$ ) [6].

Результати самозвітності про добові енерговитрати школярів дозволили визначити, що у середньому питома вага часу, який витрачався на заняття у спортивних секціях та самостійні спортивні заняття у вільний час, становила $5,85 \pm 0,17 \%(84,17 \pm 2,47$ хв на добу) загального добового бюджету часу у будні і тільки $2,01 \pm 0,11 \%(29,01 \pm 1,71$ хв на добу) - у вихідний $(p<0,01)$. Крім того, тривалість «корисної» PA хлопців (89,54 $\pm 3,21$ хв на добу) $\epsilon$ вірогідно вищою, ніж у дівчат $(77,91 \pm 3,81$ хв. на добу $(p<0,01))$ у буденний день і майже не відрізняється у вихідний (відповідно $31,39 \pm 2,42$ хв. на добу і $26,91 \pm 2,45$ хв. на добу $(p>0,1))$.

Таким чином, гендерні особливості збігаються 3 даними попередніх досліджень $[6,8,9]$ тільки стосовно бюджету часу робочого дня, коли, можливо, на рівень РА впливає ряд фракторів організаційного характеру (уроки ФК, заняття у спортивних секціях, інтенсивні фрізичні навантаження спортивного типу у повсякденному житті, наприклад, їзда на велосипеді). 3 цього випливає, що у вихідний день, незалежно від віку, тривалість і структура вільного часу школярів визначаються соціально-побутовими умовами життєдіяльності $з$ надзвичайно низькою мотивацією щодо оздоровчої фрізичної активності та надання переваги гіподинамічним формам відпочинку.

Серед соціальних фракторів, що впливають на РА дітей і підлітків, провідну роль відіграє спосіб життя, який, у свою чергу, визначається життям у різних територіальних поселеннях. Анкетне опитування показало, що добові енерговитрати учнів сільських шкіл вищі, ніж у міських школярів на $7,64 \%$ у вихідний день $(t=6,00 ; p<0,001)$ і тільки на 0,42 \% - у будні $(p>0,05)$. Встановлені відмінності пояснюються особливостями структури РА у різні дні тижня. Зокрема для школярів сільської місцевості у будній день характерним $\epsilon$ незначна перевага питомої ваги категорії РА високого рівня $(6,18 \pm 0,63 \%)$ над учнями міських шкіл $(5,78 \pm 0,17 \%,(p>0,05)$.

У вихідний день питома вага РА середньої категорії у школярів із сіл на 1,47 \% більша, ніж у міських, а висока РА дітей і підлітків сільських поселень становить 4,05 $\pm 0,45 \%$, що на 2,34 \% більше, ніж міських $(t=6,83, p<0,001)$.

Визначені особливості добового бюджету часу, на наш погляд, $є$ виправданими, зважаючи на те що діти і підлітки сіл у вільний час у вихідний і робочі дні тижня більше використовують спортивні форми дозвілля у вигляді спортивних ігор, їзди на велосипеді. Крім того, значно більша РА середньої категорії у сільських школярів виникає за рахунок господарської роботи вдома та на присадибній ділянці, ніж у школярів міських.

Інша закономірність стосується категорії дуже легкої РА, яка у вихідні зростає у 1,88 раза серед сільських і у 1,23 - серед міських школярів за рахунок відсутності необхідності йти до школи і зі школи додому (середня категорія РА) та використання вільного від навчання часу на гіподинамічні форми відпочинку або роботу за ПК.

Зважаючи на існування різних підходів до оцінки об'єму РА у наукових дослідженнях за цією тематикою, було визначено рівні енерговитрат під час РА (табл. 1) дітей і підлітків 7-17 років трьох вікових груп, загальноприйнятих для вікової градації у галузі гігієни дитинства [10].

Статево-вікове нормування РА школярів проведено за допомогою центильної шкали розподілу величини енерговитрат і не претендує на 
універсальність, враховуючи те, що дані про добовий бюджет часу отримані за результатами самозвітності учнів, та може слугувати для характеристики величин добових енерговитрат і корекції дефріциту РА у дітей шести статево-вікових груп.

За допомогою розробленої шкали енерговитрат сумарної добової РА проведено розподіл дітей за рівнями енерговитрат РА. Серед усього обстеженого контингенту найчастіше зустрічаються середній і високий рівні енерговитрат РА (відповідно $40,37 \pm 1,56$ і $33,77 \pm 1,51 \%$ ).

Встановлено, що місце проживання визначає вірогідні відмінності питомої ваги групи дітей з дуже низьким рівнем енерговитрат добової РА $(t=3,69 ; p<0,05)$. Ймовірно, такі особливості енерговитрат можна пояснити більшою питомою вагою групи високого рівня серед міських школярів за рахунок можливостей відвідувати спортивні секції, клуби, тренажерні комплекси.

Слід зазначити, що серед школярів із середнім рівнем енерговитрат переважають хлопці як міських, так і сільських шкіл - над групою дів-

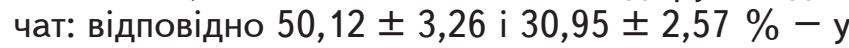
містах $(t=4,62 ; p<0,01) ; 45,45 \pm 3,65$ i $33,87 \pm 3,04-$ у селах $(t=2,44 ; p<0,05)$. Високий рівень енерговитрат вірогідно вищий у дівчат міських 3 НЗ (45,27 $\pm 2,76 \%)$ порівняно $з$ хлопцями міських шкіл $(24,94 \pm 2,82 \%$, $t=5,16 ; p<0,01)$, дівчатами $(27,42 \pm 2,86 \%$ $t=4,49 ; p<0,01)$ і хлопцями сільських шкіл $(21,21 \pm 2,99 \% t=5,93 ; p<0,01)$ за рахунок вищого динамічного компонента PA у старшому шкільному віці.

\section{Висновки}

1. Відповідно до розробленої шкали добових енерговитрат сумарної добової РА дітей 7-17 років встановлено, що серед школярів трьох вікових груп добові енерговитрати закономірно

\section{Література}

1. Використання метаболічного еквіваленту в оцінці рівня рухової активності дітей шкільного віку: метод. рек. (№ 09.11/62.11) / Н. С. Полька, І.О.Калиниченко, С. В. Гозак, Т. В. Станкевич; ДУ «Інститут гігієни та медичної екології ім. О. М. Марзєєва НАМН України», Інститут фрізичної культури Сумського державного педагогічного університету ім. А. С. Макаренка. - К., 2011. $16 \mathrm{c.}$

2. Гігієнічні проблеми донозологічної діагностики негативного впливу фракторів сучасних інформаційних наван- зменшуються 3 віком у 1,96 раза ( $t=6,64$; $p<0,05)$ і транспонуються у середній рівень енерговитрат, що зумовлено особливостями навчальної діяльності і більш гіподинамічним способом життя дітей середнього і старшого шкільного віку.

2. Статеві відмінності РА мінімізовані і характеризуються переважанням енерговитрат хлопців лише на 45,65 ккал у 16 років і 20,95 ккал - у 17 років, порівняно із дівчатами-однолітками.

3. Обсяг РА залежить від типу навчального закладу тільки у буденний день, зважаючи на відмінності в обсязі організованої РА у школах.

4. Добові енерговитрати учнів сільських шкіл на 7,64 \% переважають над енерговитратами міських школярів у вихідні і тільки на 0,42 \% - у будні, що пояснюється незначним переважанням питомої ваги категорії РА високого рівня $(6,18 \pm 0,63 \%)$ над учнями міських шкіл $(5,78 \pm 0,17 \%,(p>0,05)$ у вихідні.

\section{References}

1. The use of metabolic equivalent in evaluating the level of physical activity children of school age: methodical recommendations (№ 09.11/62.11) / N. S. Polka, I. A. Kalinichenko, S. V. Hozak, T, V. Stankevich; Institute of hygiene and medical ecology the name of O. M. Marzeeva National Academy of Medical Sciences of Ukraine, Institute of Physical Education of the Sumy State Pedagogical University of A. S. Makarenko. - Kiev: 2011. - 16 p.

2. Hygienic problems of prenosological diagnostic negative influence factors of modern information 
тажень на стан здоров'я дітей / [І. П. Козярін, О. П. Івахно, В. В. Чорна та ін.] // Гігієна населених місць. - 2010. Вип. 55. - С. 310-317.

3. До питання впливу факторів навчального процесу на морфоорункціональний розвиток школярів / [C. В. Гозак, О. Т. Єлізарова, І. О. Калиниченко та ін.] // Спортивна медицина, лікувальна фрізкультура та валеологія. - 2012: матеріали XVI Міжнар. наук.-практ. конф. (17-19 травня 2012 р.). - Одеса, 2012. - С. 39-41.

4. Калиниченко І. О. Стан здоров'я дітей у навчальних закладах з різним режимом організованої фрізичної активності / І. О. Калиниченко // Гігієна населених місць. 2009. - № 53. - С. 358-364.

5. КруцеВич Т. Ю. Методы исследования индивидуального здоровья детей и подростков в процессе физического воспитания / Т. Ю. Круцевич. - К., 1999. - 230 с.

6. Полька Н. С. Гігієнічне забезпечення умов життєдіяльності дітей у загальноосвітніх навчальних закладах / Н. С. Полька, С. В. Гозак // Гуманіт. вісник. - 2011. № 23. - C. 186-190.

7. Сила Р. В. Гигиеническая норма двигательной активности для школьников среднего и старшего школьного возраста / Р. В. Сила / / Сб. докл. II республ. съезда эпидемиологов, микробиологов, инфекционистов и гигиенистов. - Таллинн, 1972. - С. 258-261.

8. Стан здоров'я підлітків та особливості їхнього способу життя / Н. В. Медведовська, С. Д. Пономаренко, Т. К. Кульчицька [та ін.] // Україна. Здоров'я нації. 2007. - № 3-4. - С. 27-30.

9. Сухарев А. Г. Гигиеническое нормирование двигательной активности детей и подростков / А. Г. Сухарев // Научные основы гигиенического нормирования физических нагрузок для детей и подростков: сб. науч. тр. / науч. ред. А. Г. Сухарев. - М.: ВНИИГДиП, 1980. - С. 16-22.

10. Сухарев А. Г. Здоровье и физическое воспитание детей и подростков / А. Г. Сухарев. - М.: Медицина, 1991. - 272 с. to the children health / [I. P. Kozyarin, O. P. Ivakhno, V. V. Chorniy et al.] / / Hygiene of populated places. - 2010. Issue 55. - P. 310-317.

3. On the question of the influence factors of the educational process to the morphological and functional development of pupils / [S. V. Hozak, O. T. Elizarova, I. A. Kalinichenko et al.] // Sports medicine, physiotherapy and valeology. - 2012: materials of XVI International scientific and practical conference (17 - 19 of May 2012). - Odessa, 2012. - P. $39-41$.

4. Kalinichenko I. A. The state of children health in educational institutions with different modes for organized physical activity / I. A. Kalinichenko // Hygiene of populated places. - 2009. - N 53. - P. 358 - 364.

5. Krucevich T. Y. Metody researches of children and teenagers individual health in the process of physical education / T. Y. Krucevich. - Kiev, 1999. - 230 p.

6. Polka N. S. Hygienic providing of living children conditions in general education institutions / N. S. Polka, S. V. Hozak // Humanitarian Journal. - 2011. - N 23. - P. 186-190.

7. Sila R. V. Hygienic norm physical activity for pupils middle and high school age / R. V. Sila // Collection of reports II congress of the Republican epidemiologists, microbiologists, infectious disease specialists and hygienists. - Tallinn, 1972. - P. 258-261.

8. State of teenagers health and features their life style / N. V. Medvedovskaya, S. D. Ponomarenko, T. K. Kulchytska [et al.] / / Ukraine. Nation Health of the. - 2007. - N 3-4. P. 27-30.

9. Sukharev A. G. Hygienic standardization of children and teenagers physical activity / A. G. Sukharev // scientific basis of hygienic standardization of physical activity for children and teenagers: collection of scientific papers / scientific editor A. G. Sukharev. - Moscow : VSRIHCT, 1980. - P. 16-22.

10. Sukharev $A$. G. Health and physical education of children and teenagers / A. G. Sukharev. - Moscow: Medicine, 1991. $-272 \mathrm{p}$. 